УДК 598.2:591.552 (571.65)

\title{
СОСТОЯНИЕ КОЛОНИЙ МОРСКИХ ПТИЦ ПОЛУОСТРОВА СТАРИЦКОГО (Тауйская губа, Охотское море)
}

\author{
Зеленская Л. А. \\ ФГБУН Институт биологических проблем Севера, г. Магадан \\ E-mail: larusrissa@gmail.com
}

\begin{abstract}
Сравнение учетных данных 2019 г. с полученными ранее позволяет оценить изменения, произошедшие за последние 10 лет в гнездовых колониях морских птиц п-ова Старицкого и его окрестностей. Побережье п-ова Старицкого и острова в акваториях бухт Гертнера и Веселая находятся в непосредственной близости к г. Магадану и подвергаются максимальной антропогенной нагрузке. Общая численность гнездящихся морских птиц (учитывая и урбанизированную популяцию тихоокеанской чайки г. Магадана) возросла с 36 тыс. особей в 2009 г. до 57.6 тыс. особей по данным последних учетов. Параллельно происходит перераспределение соотношения фоновых видов в самых крупных колониях, расположенных рядом с городом, - на о-вах Три Брата и м. Островной. Появившаяся в последние 20 лет крупная колония беринговых бакланов (3.2 тыс. особей) близ устья р. Дукча сейчас самая большая в Тауйской губе. Ее формированию и росту способствовал сброс неочищенных городских сточных вод в акваторию бух. Гертнера.
\end{abstract}

Ключевые слова: колонии морских птиц, численность морских птиц, размещение колоний, антропогенное загрязнение акватории, Тауйская губа, п-ов Старицкого, о-ва Три Брата, м. Островной.

DOI: 10.34078/1814-0998-2021-2-87-98

\section{ВВЕДЕНИЕ}

Несмотря на близкое соседство с городом, изучение колоний морских птиц в окрестностях г. Магадана началось лишь в последние 30 лет. После первого упоминания А. П. Васьковского (1956) о птицах колонии о-вов Три Брата в бух. Веселая, которые он посещал в 1947 г., следующие учеты вокруг п-ова Старицкого были проведены только в 1991 г. (Голубова, Плещенко, 1997). В 2005 и 2006 г. мы повторили учеты на колониях м. Островной и о-вов Три Брата. Были отмечены значительные изменения как в численности птиц, так и в видовом составе. Стало ясно, что назрела необходимость в регулярном слежении за состоянием этих колоний для использования результатов учетов как индикатора экологического состояния прибрежных вод вокруг г. Магадана и для оценки антропогенной нагрузки на колонии. Были проведены фотоучеты в 2009 г. на м. Островной и о-вах Три Брата и учеты с лодки на побережье п-ова Старицкого и его окрестностей (Зеленская, 2012, 2013).

В течение ряда лет продолжалось накопление информации о состоянии гнездовых колоний морских птиц в окрестностях г. Магадана. Одновременно мы отслеживали необычный процесс адаптации одного из фоновых видов

(C) Зеленская Л. А., 2021 морских птиц Тауйской губы - тихоокеанской чайки (Larus schistisagus) - к условиям города. C 1998 г. чайки начали гнездиться на крышах городских зданий (Зеленская, 2004). Этот процесс успешно развивался, и в настоящее время в городе образовалась устойчивая урбанизированная популяция, имеющая ряд черт, отличающих ее от природных популяций (Зеленская, 2019а, б).

В данной работе представлены все собранные нами материалы, обработанные по единым методикам. Целью работы было выявление изменений, произошедших за последние 10 лет в численности морских птиц, в распределении колоний в зоне максимального антропогенного пресса, а также попытка объяснить эти явления.

\section{МАТЕРИАЛ И МЕТОДЫ}

Район исследования. Полуостров Старицкого омывают четыре бухты (рис. 1). В бух. Светлая и Нагаева островов нет. В акватории бух. Гертнера расположен о. Кекурный (Монах), в бух. Веселая - о. Вдовушка и группа мелких о-вов Три Брата у м. Восточный (рис. 1). На обсыхающем в период отлива о. Вдовушка гнездовий морских птиц нет. Полуостров Старицкого и окружающие его бухты - наиболее подверженные антропогенному прессу участки морского побережья в Магаданской области. С позиции антропогенного влияния на колонии морских птиц 


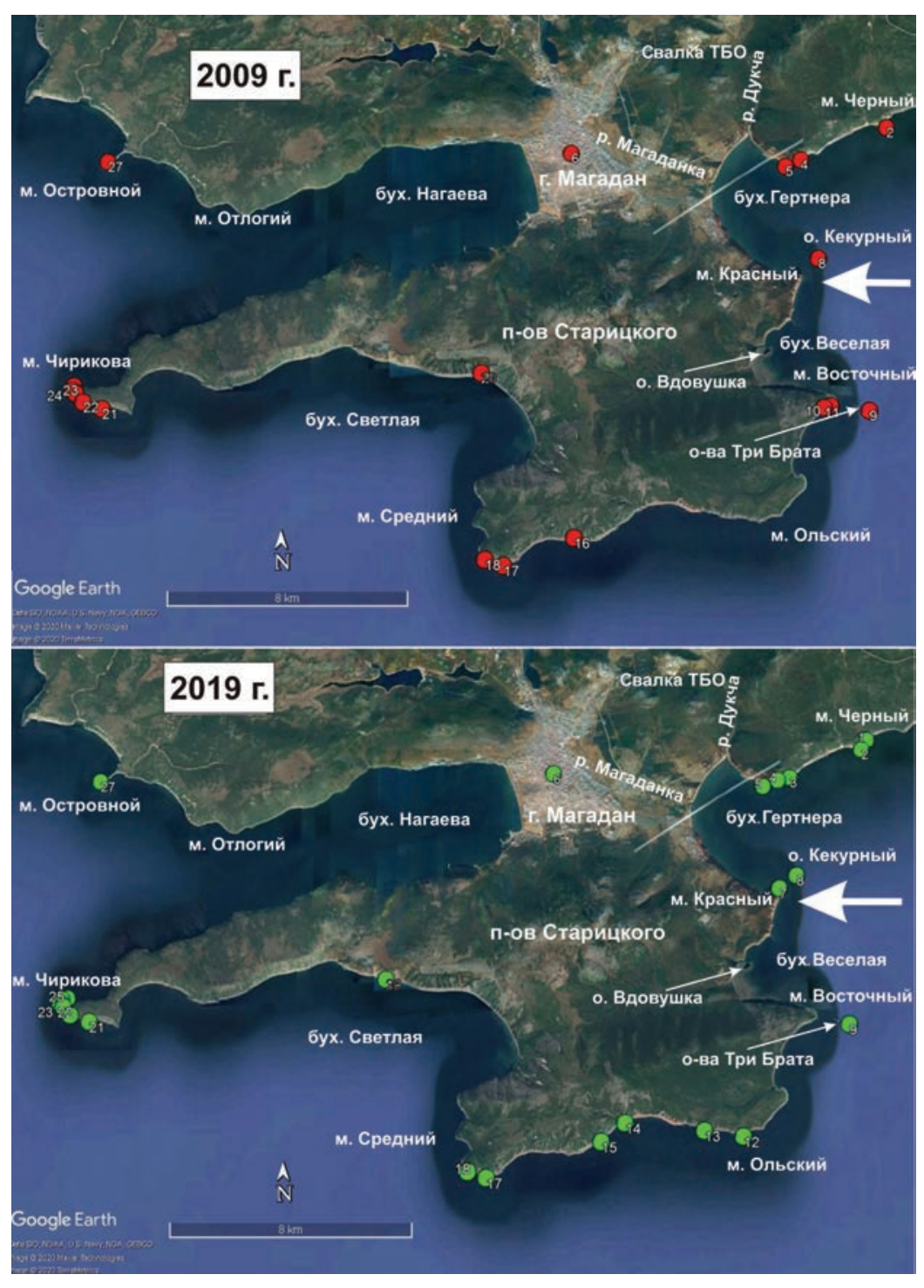

Puc. 1. Распределение колоний морских птиц на п-ове Старицкого и в окрестных бухтах в разные годы. Большой стрелкой показано место сброса городских сточных вод

Fig. 1. Seabird colonies distribution on the Staritsky Peninsula and in the surrounding bays in different years. Large arrow indicates the place of urban wastewaters discharge

в гнездовой период (апрель - сентябрь) важнейшими являются следующие компоненты района исследования.

1. Территория постоянного / регулярного присутствия людей на суше. На перешейке полуострова между бух. Нагаева и Гертнера расположен областной центр г. Магадан (рис. 1). Городская застройка занимает весь перешеек. Берега бух. Нагаева рядом с городом - территории торгового и рыбного портов, в мелководной части бухты расположен городской пляж. Вдоль южного берега бух. Нагаева грунтовая дорога позволяет проехать от города не далее 3 км (до руин складов). Есть грунтовая дорога в бух. Веселая до моря около о. Вдовушка за руинами брошен- ного пос. Старая Веселая (рис. 1). На территории п-ова Старицкого и окрестных бухт нет постоянных поселений, кроме маячного хозяйства на м. Чирикова и дачного района, протянувшегося вдоль берега от бух. Гертнера до м. Красный. Отсутствие дорог, горная местность, сложная для пеших маршрутов, и обрывистые берега оставляют ландшафты полуострова почти не затронутыми антропогенным воздействием.

Ягоды и грибы население собирает, как правило, рядом с городом. В 1990-е гг. резко возросла активность населения по сбору яиц морских птиц, в основном тихоокеанской чайки. Активному ограблению подвергались самые крупные колонии в окрестности города: м. Островной и о-ва Три Брата (Зеленская, 2012). Но несколько трагических несчастных случаев и общий выход из кризиса постепенно снизили эту активность, и в настоящее время стихийный сбор яиц является скорее случайным развлечением отдельных людей во время рыбалки около колоний.

2. Территория постоянного / peгулярного присутствия людей на воде и побережье. Мелководные бух. Гертнера и Веселая - традиционные места отдыха горожан на берегу. Всё побережье от м. Черный (бух. Гертнера) до м. Островной (бух. Нагаева) (рис. 1), постоянно используется городским населением для отдыха и рыбалки на весельных и моторных лодках. Численность маломерного флота и рекреационная активность населения увеличиваются с каждым годом. Узкие береговые пляжи от м. Черный (бух. Гертнера) до бух. Веселая регулярно используются населением для пеших прогулок и рыбалки с берега. На всем побережье устраиваются стихийные рыбацкие базы и зоны пикников. Постоянные зоны пикников расположены в бух. Веселая около о. Вдовушка, на южном побережье бух. Нагаева за территорией рыбного порта и в бух. Гертнера в устье р. Дукча, в которую заходит на нерест горбуша (Oncorhynchus gorbuscha). Около устья р. Дукча в черте города открыта зона лицензионного лова лососевых рыб. В весенний период здесь же традиционно происходит любительский лов сельди (Clupea pallasi) 
сетями с берега. У м. Чирикова и м. Островной традиционные места любительской глубоководной рыбалки: треска (Gadus macrocephalus), морской окунь (Sebastes glaucus), камбалы (Liopsetta glacialis, Platichthys stellatus), минтай (Theragra chalcogramma). Южный берег бух. Нагаева, м. Восточный и Островной являются традиционными для горожан местами лова крабов.

3. Загрязнение акватории. В бух. Нагаева в ручьи, впадающие в районе городского пляжа, десятилетиями происходил сброс сточных вод. С вводом в эксплуатацию канализационной насосной станции в микрорайоне Нагаева в 2013 г. был ликвидирован канализационный выпуск в бух. Нагаева и сточные воды перенаправлены на механические очистные сооружения города.

В бух. Гертнера впадают протекающая через город р. Магаданка и р. Дукча. Река Магаданка всегда служила коллектором для отвода промышленных и коммунальных сточных вод. В 1990-х гг. в городе был закрыт ряд промышленных предприятий, в том числе шиноремонтный и кожзавод, которые привносили наиболее значительное загрязнение. В 1992 г. были введены в эксплуатацию городские канализационные сооружения механической очистки. Стоки от основной части города проходили механическую очистку и сбрасывались в бух. Гертнера через подводную трубу между бух. Гертнера и Веселая, рядом с м. Красный (см. рис. 1, показано толстой стрелкой). Механические очистные сооружения не обеспечивали нормативную очистку сточных вод.

С 2008 по 2018 г. шло строительство очистных сооружений биологической очистки с проектной мощностью 65 тыс. м $^{3}$ стоков в сутки. Новые очистные сооружения были сданы в январе 2018 г., но нормативно они не работали. Сброс сточных вод в бух. Гертнера продолжался до конца августа 2018 г. В настоящее время сброс очищенных сточных вод происходит по самотечному отводящему коллектору в р. Магаданка.

4. Свалка доступных для птиц пищевых отходов. На расстоянии около 4 км от устья р. Дукча расположен полигон твердых бытовых отходов (ТБО, рис. 1) г. Магадана. Год ввода в эксплуатацию полигона - 1972, расчетный год окончания эксплуатации - 2025. Мощность объекта составляет 54.5 тыс. т отходов в год.

Сроки и объекты учетов. Были использованы следующие неопубликованные ранее материалы: 1) серия фотографий для фотоучета, специально выполненная О. А. Мочаловой (ИБПС ДВО РАН) на м. Островной 16.06.2011 г. Остальные материалы были получены автором; 2) фотоучет на м. Островной сделан 25.07.2016 г. 3) учеты на м. Красный и о. Кекурный (Монах) проведе- ны 23.07.2017 г.; 4) фотоучет на о-вах Три Брата выполнен 11.08.2017 г.; 5) учет морских птиц в колониях на побережье от р. Конгали (бух. Гертнера) (№ 1, рис. 1) до м. Островной (бух. Нагаева) (№ 27, рис. 1) проведен 21.07.2019 г. Протяженность маршрута составила 104 км.

В колониях на морском побережье и островах гнездились следующие виды морских птиц: берингов баклан (Phalacrocorax pelagicus), тихоокеанская чайка (Larus schistisagus), моевка (Rissa tridactyla), тонкоклювая кайра (Uria aalge), толстоклювая кайра (Uria lomvia), очковый чистик (Cepphus carbo), топорок (Lunda cirrhata), ипатка (Fratercula corniculata), белобрюшка (Cyclorrhynchus psittacula). Видовые названия птиц приводятся по аннотированному каталогу (Нечаев, Гамова, 2009).

Краткое описание колоний морских птиц на побережье уже приводилось (Голубова, Плещенко, 1997), так же как и описание колоний о-вов Три Брата и м. Островной (Зеленская, 2012). Краткие описания биотопов будут приводиться только при возникновении изменений в старых колониях и при характеристике новых.

Методы учета птиц. Все учеты начинались с раннего утра. Основная часть учетных работ проведена с борта моторной лодки, «однократным проходом» в ясную погоду, при хорошей видимости и отсутствии волнения на море, в течение светового дня, при помощи 8-кратного бинокля. Методы и способы подсчета птиц были едиными во все годы.

Берингов баклан и моевка. Учитывали количество занятых гнезд, поскольку эти виды птиц не оставляют гнездо без присмотра. Птиц на воде и в «клубах» не считали, поскольку задачей было учесть именно гнездящуюся часть популяций, а в группах отдыхающих и кормящихся птиц велика вероятность концентрации не размножающихся и, судя по оперению, неполовозрелых особей. Количество учтенных занятых гнезд удваивали (учитывая партнера), получая численность особей в колонии.

Тихоокеанская чайка. Птиц в «клубах» и на воде не учитывали. Число птиц, обнаруженных на гнездовьях, умножали на коэффициент 0.75. Данный коэффициент мы получили методом, опробованным на Командорских островах в 2007 г.: на различных (по характеру растительного покрова, рельефу, уклону и пр.) модельных площадках два учетчика, независимо друг от друга, в пешем маршруте методично просчитывали все гнезда серокрылых чаек (Larus glaucescens). Затем те же площадки с гнездами также два учетчика независимо просматривали в бинокль (не тревожа колонию) и просчитывали всех находящихся там птиц. Число гнезд при учетах «проходом» считали «истинным». Число птиц, учтен- 
ных в бинокль без беспокойства, как правило, не соответствовало количеству гнезд, поскольку рядом с гнездом могут находиться как оба партнеpa, так и один. По нашим расчетам, оптимальным для получения «истинного» результата был коэффициент 0.75 (Артюхин, Зеленская, 2008). Этот способ расчета был проверен на очень близком по поведению в гнездовой период виде - тихоокеанской чайке на колониях о. Шеликан и островных барах Ольской лагуны. Коэффициент «хорошо работал». Полученное число гнезд удваивали, получая число гнездящихся особей.

Очковый чистик. В 2011 г. на м. Островной учет чистиков на воде не проводили (только птицы, попавшие на фото на берегу). В 2016 г. мы выполняли отдельный учет очковых чистиков вдоль периметра острова с борта моторной лодки в период их наибольшей активности (раннее утро). Однако море было не спокойным и в учет могло не попасть много птиц, сидящих на воде и закрытых от наблюдателя волнами. Данные по этому виду в 2016 г. скорее ориентировочные.

Кайры. Оба вида кайр, как правило, не оставляют гнездо без присмотра, их учитывали только на гнездовых карнизах методом фотоучетов. Однако мы не всегда имели возможность точно идентифицировать вид кайры на фото, поэтому оба вида кайр представлены в таблице совместно. Проводя каждый учет, периодически обязательно осматривали в бинокль карнизы и скопления птиц на скалах и воде для выяснения процентного соотношения видов, при наличии обоих видов на колонии. В случае моновидовых колоний высматривали хотя бы единичных особей второго вида. В колонии м. Островной были обнаружены только тонкоклювые кайры. На о-вах Три Брата отмечено значительное преобладание численности тонкоклювой кайры (более 95 \%), что вообще характерно для нашего региона (Голубова, 2014).

В учеты попадали все кайры на скалах, так как карнизы везде были узкими. Мы не имели возможности провести повторные учеты и потому старались придерживаться единства методов учета во все годы. Все обследования, как правило, проводились примерно в одно время гнездового цикла - в середине-конце июля, примерно в одно время суток - в первой половине дня. Регистрируя всех птиц на карнизах и понимая, что гнездятся далеко не все из учтенных особей, численность кайр в таблице приведена без поправочного коэффициента.

Топорок. Число топорков, отмеченных на берегу и на воде около колонии, умножалось на 5 , так как полевые работы (методичные проверки всех обнаруженных нор на заселенность на модельных площадках), проведенные на о. Топорков (Командоры) показали, что обычно только около одной из трех-четырех занятых гнездовых нор мы можем видеть птицу, и нужно учесть и второго партнера. Наш почти 30 -летний опыт работ на различных островах-колониях и в акватории Охотского моря и на Командорских островах не дает основания полагать, что есть существенные различия в стереотипах гнездового поведения топорков в разных колониях.

Учитывая, что количество топорков как на поверхности колонии, так и на воде меняется не только в течение суток, но и резко колеблется день ото дня - различия могут быть в разы и более, к приведенным нами данным следует относиться с осторожностью, это скорее ориентировочные цифры.

Ипатка и белобрюшка. Птиц просчитывали как на берегу, так и на воде, так как у берегов держатся гнездящиеся особи. У ипатки число особей удваивали, учитывая гнездового партнера. Численность очень редкой в этом районе белобрюшки приведена без пересчетов. К цифровым данным по численности ипатки, приведенным в таблице, следует относиться с осторожностью, как к ориентировочным.

Методика фотоучетов. Цифровым зеркальным фотоаппаратом были подробно отсняты скалы и обрывы, далее снимки были обработаны в программе Photoshop. Участки скальных склонов на мониторе оконтуривали и состыковывали во избежание повторных учетов тех же птиц или пропусков поверхности склона. Затем птиц просчитывали, маркируя каждую особь (кайры, чайки) или гнездо (моевки и бакланы) при увеличении, достаточном для точной идентификации видов. Этот метод позволяет учитывать не только численный и видовой состав колонии, но и пространственное распределение видов.

\section{РЕЗУЛЬТАТЫ}

Распределение колоний по побережью представлено на рис. 1. Для сравнения местоположения колоний в разные годы на рисунке показано распределение колоний, зафиксированных в предыдущем нашем учете 2009 г. Численность морских птиц каждого вида представлена в таблице. В опубликованных данных предыдущих учетов (Зеленская, 2013) не приводилось координат колоний, поэтому в таблице они представлены для всех колоний, даже исчезнувших в настоящее время. Нумерация колоний сквозная, в порядке следования лодки. Номера колоний в таблице соответствуют номерам колоний на рисунке. Это позволяет отследить как исчезновение, так и появление отдельных колоний. Для сравнения в таблице приведена численность каждого вида по результатам учетов 2009 г. Следует отметить, что для колоний № 8 и 9 (о. Кекурный и о-ва Три Брата) в графе «2019» приведены данные последнего учета в 2017 г. Для колонии № 27 
(м. Островной) в графе «2019» приведены данные последнего учета в 2016 г.

В бух. Светлая и Нагаева нет колоний морских птиц. Единственное исключение - небольшая колония чаек в бух. Светлая (см. рис. 1).

Повидовые изменения в численности и распределении морских птиц.

Берингов баклан. Общая численность за последнее десятилетие в этом районе выросла более чем втрое (см. таблицу). В основном рост численности бакланов происходит в бух. Гертнера. Участок побережья, носящий в просторечии название «Горняк», - безымянный мыс левее устья р. Дукча (№ 3-5, рис. 1; см. таблицу). Точка начала колонии (№ 3) расположена у высоты 246 на топографических картах, № 4, 5 у высоты 101.7. Протяженность участка побережья, занятого колонией на «Горняке», чуть более 1 км. Так как точка № 4 служит скорее ориентиром, отчеркивающим границу между двумя частями протяженной колонии, в таблице ее нет. В 2009 г. учет выполнялся только на участке № 4, 5 (протяженность 0.56 км), в 2019 г. учет был проведен на всем участке (№ 3-5). Второй участок побережья (№ 3, 4, протяженность 0.53 км) в 2009 г. не был заселен морскими птицами. На том же участке побережья бух. Гертнера, на ближайшем скальном обрыве - м. Черный (№ 2, рис. 1), расположена следующая стремительно растущая колония бакланов. В 2009 г. здесь не было гнезд, в настоящее время - более 900 (см. таблицу).

На выходе из бух. Гертнера стремительно растет численность бакланов еще в двух колониях: в береговой, возникшей в последнее десятилетие на м. Красный (№ 7, рис. 1) и на о. Кекурный (№ 8, рис.1). Колония на островке известна давно, но если в 2009 г. здесь было только 2 гнезда бакланов, то через 10 лет - более 100 (см. таблицу). В то же время на крупнейших колониях - о-вах Три Брата (№ 9, рис. 1) численность бакланов изменилась незначительно, а на южном побережье п-ова Старицкого и в бух. Веселая их численность уменьшилась (см. таблицу). Только в двух крайних колониях на выходе из бух. Нагаева: на м. Островной (№ 27, рис. 1) и в новой колонии на м. Чирикова (№ 26, рис. 1) колонии бакланов растут (см. таблицу).

Тихоокеанская чайка. Это единственный вид из морских птиц, который успешно адаптировался к условиям городской застройки (№ 6, рис. 1). В г. Магадане сформировалась урбанизированная популяция, которая успешно размножается на крышах городских зданий, несмотря на перманентные попытки владельцев зданий уничтожать гнезда. Продуктивность городских чаек значительно выше, чем в окружающих природных колониях, темпы роста городских колоний оклоло 13 \% в год (Зеленская, 2019а). Чис- ленность гнездящихся чаек выросла втрое за последнее десятилетие (см. таблицу). Одновременно рост численности чаек происходит в колониях на побережье бух. Гертнера (№ 1, 2-5) и у выхода канализационного коллектора (№ 7, 8), и в большинстве колоний на южном побережье п-ова Старицкого (см. таблицу). В то же время на самых крупных колониях морских птиц - о-вах Три Брата и м. Островной численность тихоокеанской чайки стабильна. При этом отдельные колонии тихоокеанских чаек исчезают, в некоторых падает численность их гнезд.

Моевка. Стремительный рост численности у моевки отмечен во всех колониях, включая появившиеся в последние 10 лет (см. таблицу). Единственное исключение - колонии на м. Чирикова около маяка (№ 24, 25, рис. 1). Только в этих двух колониях число гнезд уменьшилось (см. таблицу).

Кайры. Кайры продолжают гнездиться в двух крупнейших колониях: М. Островной (№ 27) и о-ва Три Брата (№ 9) (рис. 1). Преимущественно это тонкоклювая кайра. Толстоклювая кайра есть только в колонии о-вов Три Брата, и это скорее редкие пары. В таблице оба вида представлены суммарно. Численность кайр в обеих колониях растет: в 1.3 раза на о-вах Три Брата, в 2.4 раза на м. Островной (см. таблицу). Зафиксирована единичная особь на вершине о. Кекурный. Это первая регистрация тонкоклювой кайры на этом островке.

Очковый чистик. В связи с тем, что учеты чистиков проводились не в оптимальное время для учетных работ, и даже на м. Островной состояние моря не позволило провести учет корректно, к полученным данным нужно относиться осторожно. Это скорее - оценочные данные. Можно уверенно говорить только о росте численности гнездящихся чистиков на о-вах Три Брата и в районе м. Черный (см. таблицу).

Топорок. В 2009 г. топорок в небольшом количестве гнездился в трех колониях: на о-вах Три Брата (№ 9), м. Островной (№ 27) и м. Чирикова (№ 25) (рис. 1). За последнее десятилетие численность топорков почти в 5 раз увеличилась на о-вах Три Брата и появились первые пары на о. Кекурный (№ 8), но на м. Чирикова их численность упала вдвое (см. таблицу).

Ипатка. По-прежнему очень немногочисленный вид в окрестностях п-ова Старицкого. Однако если ранее ипатка гнездилась только на м. Островной, то в настоящее время распространение ее гнездовий значительно расширилось (см. таблицу). Численность на м. Островной увеличилась ориентировочно почти в 5 раз (см. таблицу).

Белобрюшка. В 2017 г., впервые за многие годы отсутствия в этом районе, вид-планктофаг был зарегистрирован на колониях о-вов Три Брата. Ранее белобрюшка наблюдалась «в тече- 


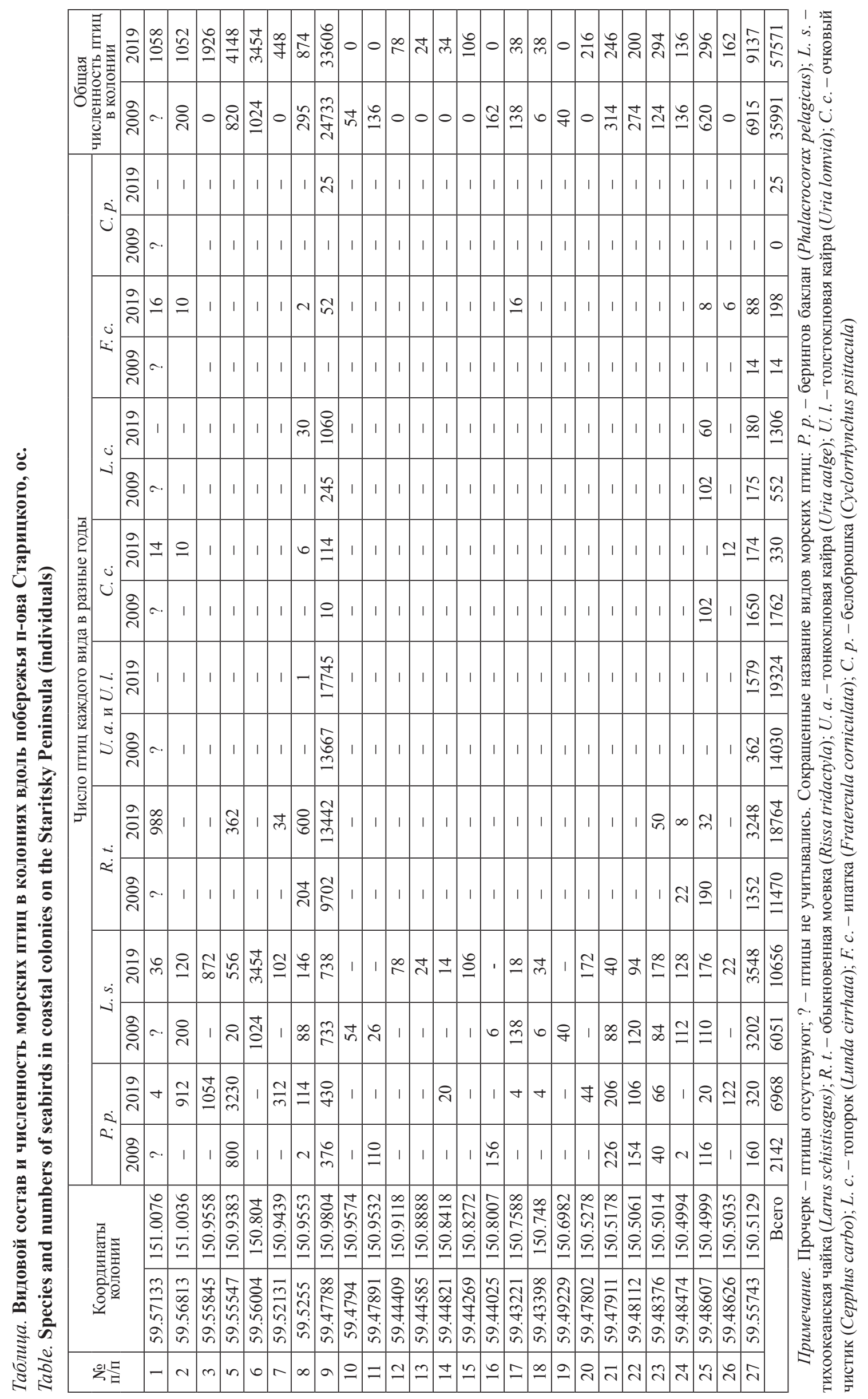


ние многих лет на птичьем базаре о-вов Три Брата в бух. Веселой» только в конце 1940-х гг. А. П. Васьковским (1956).

Изменения в распределении и состоянии колоний. Применение GPS картирования колоний в 2009 и 2019 г. позволяет точно знать, происходило ли перераспределение, исчезновение или появление новых колоний на морском побережье. На участке обследованного побережья от устья р. Конгали до м. Островной включительно в 2009 г. было обнаружено 15 смешанных и моновидовых колоний морских птиц, в 2019 г. - 20 колоний (см. рис. 1, таблицу). За десять лет 4 колонии исчезли и возникли 8 колоний на новых участках. Мы наблюдаем в бух. Гертнера появление трех колоний с большой численностью птиц: 10.5 тыс., 1.9 тыс. и 0.5 тыс. особей. Отмечено возрастание численности птиц в ранее существующих береговых колониях в 3.5 раза (см. таблицу).

В южной части п-ова Старицкого от м. Восточный до м. Ольский остались только островные колонии, две небольшие береговые - исчезли (см. рис. 1). Далее на побережье от м. Ольский до м. Средний появились 4 новые, небольшие по численности, а исчезла только одна (см. таблицу). В бух. Светлая одна маленькая колония исчезла и одна более крупная появилась на новом месте, на м. Чирикова возникла еще одна колония (см. рис. 1, таблицу).

Самое значительное изменение в распределении колоний морских птиц на побережье - появление и стремительный рост колонии «Горняк», которая ранее не описывалась. Примерно в середине протяженной береговой колонии гнезда исчезают (№ 3, рис. 1), поскольку здесь в долине ручья более пологие береговые склоны становятся доступными для отдыхающих людей и сопровождающих их собак. На участке № 3, 4 нет вертикальных скальных стен, соответственно нет моевок.

Крутые обрывы со скальными выходами поддерживают смешанные колонии тихоокеанской чайки и берингова баклана (см. таблицу). По соотношению числа гнезд на участке № 4, 5, бакланов больше в 6 раз (см. таблицу). Гнезда чаек «вкраплены» на редких пологих участках, недоступных для наземных хищников как сверху, так и снизу обрывов. Расстояние между гнездами бакланов часто лишь чуть далее расстояния вытянутой шеи птицы-соседки, их птенцы до подъема на крыло практически не покидают территории гнезда. Относительно небольшие пространства трещин и расселин на стенах, подходящие для строительства гнезд, заполнены максимальным количеством размножающихся пар бакланов. На участке № 3, 4 соотношение численности этих видов почти равное. Бакланьи «городки» занимают «неудобья» между мелкими колониями чаек на относительно пологих местах обрывов, так как чайки нуждаются в просторных гнездовых участках для нормальной активности их птенцов. В отсутствие непосредственного разорения гнезд антропогенный пресс в виде постоянного присутствия людей на берегу под колонией или на воде переносится бакланами легко.

Значительные перемены произошли в состоянии островных колоний. В трех островных колониях гнездится 75.8 \% морских птиц, размножающихся на изучаемой территории: о. Кекурный $-1.5 \%$, м. Островной - $15.9 \%$, о-ва Три Брата $-58.4 \%$.

На очень маленьком по площади о. Кекурный (№ 8, рис. 1) численность птиц выросла в 3 раза. Состав колонии изменился. Моевки, как и раньше, составляют две трети от численности колонии. Стремительно возросла численность гнездящихся бакланов - они почти сравнялись по численности с тихоокеанской чайкой (см. таблицу).

По учетам в 2016 г. численность морских птиц, гнездящихся на м. Островной, снизилась по сравнению с 2011 г., но остается выше, чем в 2009 г. (рис. 2). Соотношение фоновых видов морских птиц, гнездящихся на м. Островной, также изме-

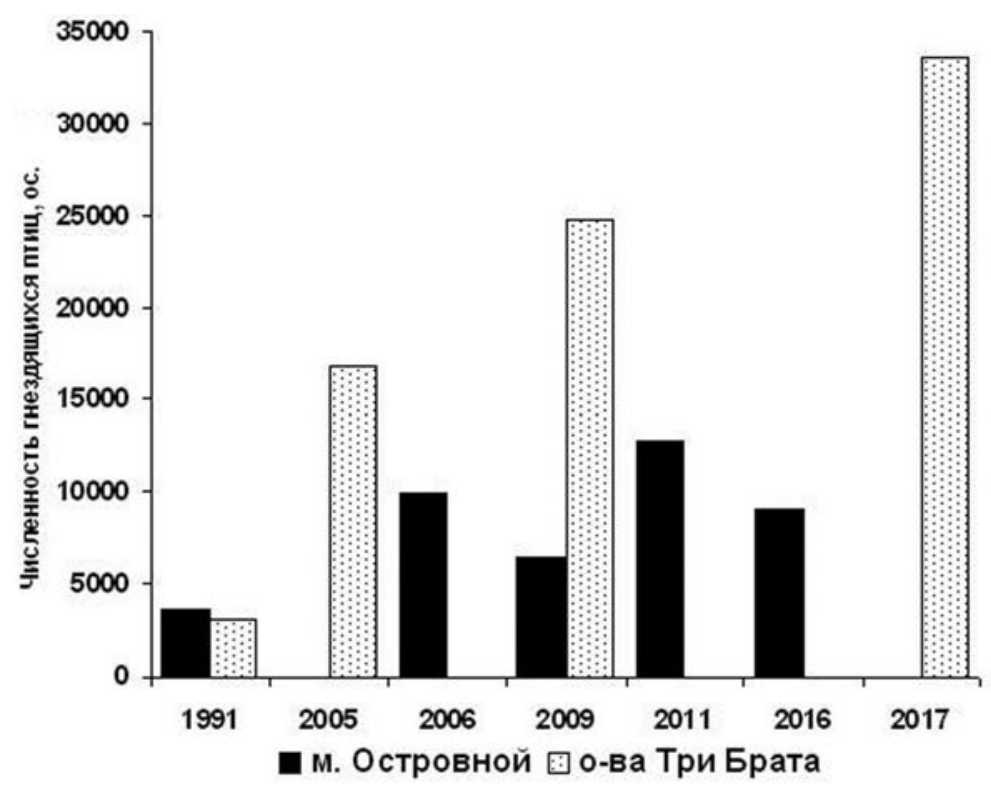

Puc. 2. Изменение численности морских птиц, гнездящихся в колониях м. Островной и о-вов Три Брата в разные годы. Данные 1991 г. приведены по: Голубова, Плещенко, 1997

Fig. 2. Change in the number of seabirds breeding on Cape Ostrovnoy and on the Tri Brata Islands in different years; the 1991 data after Golubova, Pleschenko, 1997 


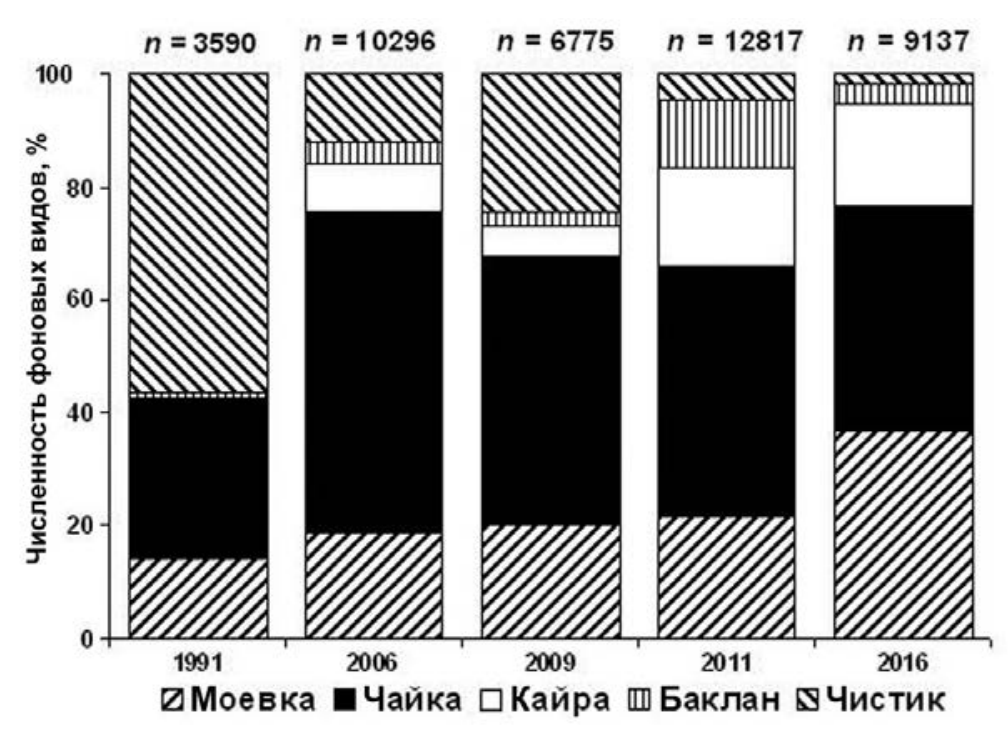

Pис. 3. Соотношение численности фоновых видов колонии морских птиц на м. Островной в разные годы. $n$ - общая численность птиц (ос.). Данные 1991 г. приведены по: Голубова, Плещенко, 1997

Fig. 3. Proportion of the main species abundance at the Cape Ostrovnoy seabird colony in different years; $n$ as the total number of birds (individuals); the 1991 data after Golubova, Pleschenko, 1997

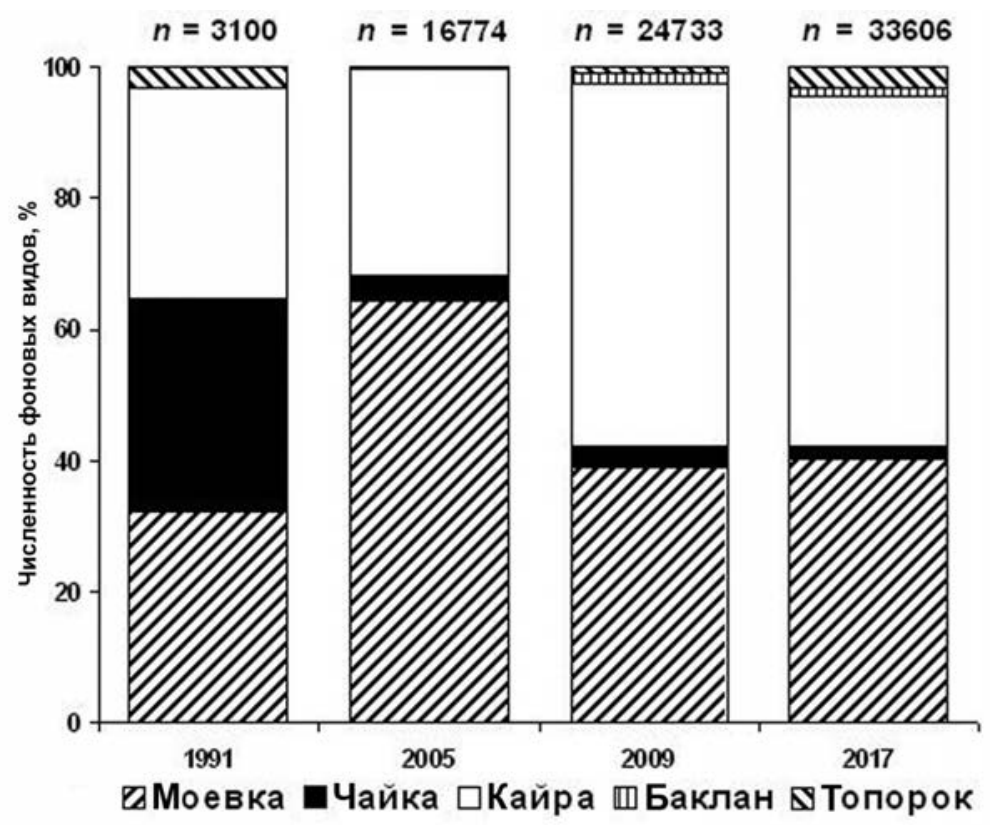

Pис. 4. Соотношение численности фоновых видов колонии морских птиц на о-вах Три Брата в разные годы. $n$ - общая численность птиц (ос.). Данные 1991 г. приведены по: Голубова, Плещенко, 1997

Fig. 4. Proportion of the main species abundance at the Tri Brata Islands seabird colony in different years; $n$ as the total number of birds (individuals); the 1991 data after Golubova, Pleschenko, 1997

нилось: растет доля гнездящихся моевок и кайр, а доля тихоокеанских чаек и очковых чистиков снижается. Сейчас основная масса гнездящихся здесь морских птиц представлена обыкновен- ной моевкой, тихоокеанской чайкой и тонкоклювой кайрой (рис. 3).

Самая крупная колония морских птиц, размещающаяся на о-вах Три Брата, стремительно растет на протяжении всех лет наблюдений (см. рис. 2). Процентное соотношение численности фоновых видов гнездящихся морских птиц здесь немного изменилось с 2009 г. (рис. 4). По-прежнему основная масса гнездящихся птиц представлена тонкоклювой кайрой и обыкновенной моевкой. Численность гнездящихся топорков возросла и превысила долю тихоокеанской чайки в этой колонии (рис. 4).

\section{ОБСУЖДЕНИЕ}

Береговые колонии. Полуостров Старицкого и его окрестности зона максимального антропогенного пресса для гнездящихся морских птиц, и можно было бы ожидать снижение их численности в береговых колониях. Мы это и наблюдаем на м. Восточный и в непосредственной близости к маяку на м. Чирикова, где активность людей высока и, как следствие, исчезли отдельные мелкие колонии. И только между м. Средний и м. Ольский, где очень коварный накат, мешающий высадке людей на берег с моря, а обрывистые берега не дают возможность людям спуститься к морю сверху, появились новые колонии, в которые, вероятно, и переместились морские птицы.

Однако именно в наиболее беспокойных для птиц местах - в зоне городской застройки и на берегах мелководной бух. Гертнера - продолжается стремительный рост численности гнездящихся морских птиц. Особенности экологии урбанизированной популяции тихоокеанской чайки подробно рассматривалась ранее (Зеленская, 2004, 2019а, б). Стремительному росту численности чаек в городе способствуют два основных фактора: 1) относительная безопасность их гнезд от хищников. Крыши зданий недоступны для любых животных, а пернатые хищники, представляющие реальную угрозу для крупных чаек, - ворон (Corvus corax) и орланы (Haliaeetus pelagicus и H. albicilla) - избегают городскую застройку. 
В городе исчезает и внутривидовое хищничество, характерное для чаек в природных колониях. Человек, уничтожающий гнезда и птенцов, ведет себя крайне непоследовательно: убирает то все гнезда, то часть гнезд, а чаще - вообще их не замечает. Многие крыши изолированы от попыток проникновения туда людей и полностью безопасны для чаек; 2) доступные дополнительные корма: выбрасываемые пищевые отходы, отходы рыбы и пищи у рыбаков-любителей и отдыхающих, городские голуби (Columba livia) (3eленская, 2019б). Городской полигон ТБО рядом с побережьем играет в этом важнейшую роль.

Отмеченный взрывной рост урбанизированной популяции не может основываться только на пополнении потомством гнездящихся на крышах чаек. Эта популяция является составной частью гнездящихся морских птиц Тауйской губы и, скорее всего, неразрывно связана с окружающими город природными колониями процессами иммиграции и эмиграции. Рост численности урбанизированной популяции продолжается, и гнездовья распространяются все шире по территории городской застройки в течение всех лет наблюдений (с 2004 г.) (Зеленская, 2019а).

Основная пищевая ниша берингова баклана донный и придонный водные слои на небольших глубинах моря (Зеленская, 2001). Бухта Гертнера в период отлива представляет собой илистую отмель, омываемую водами двух рек - Магаданки и Дукчи, и занятую тысячами сизых (Larus canus) и тихоокеанских чаек, активно добывающих беспозвоночных из ила. Беринговы бакланы и моевки кормятся здесь в период прилива. Сизые чайки в бух. Гертнера только кормятся, а остальные виды стремятся гнездиться рядом с пищевым ресурсом. Стремительно выросло число гнезд у морских птиц в береговых колониях бух. Гертнеpa с 2009 по 2019 г.: у моевки - с 0 до почти 700, у берингова баклана увеличилось в 7 раз, тихоокеанской чайки - в 8 раз. В районе бух. Гертнера на материковом берегу почти нет скал, подходящих для устройства гнезд моевки. Поэтому единственная скала в устье р. Конгали (№ 2, рис. 1) поддерживает очень плотную колонию и даже не очень подходящие для вида участки берега на м. Красный и «Горняке» используются моевкой для гнездования (см. таблицу).

Стремительный рост численности гнездящихся беринговых бакланов в колониях «Горняк», м. Красный и м. Черный, а также тот факт, что сравнительно недавно, в 1980-х гг. здесь вообще не было гнезд морских птиц, наводит на мысль о резко возросшей и остающейся высокой на протяжении ряда лет продуктивности вод бух. Гертнера, что, вероятно, связано с притоком биогенов из сброса практически не очищенных коммунальных сточных вод у м. Красный (см. рис. 1, показано стрелкой). Возможно, увеличению продукции бентоса бух. Гертнера дополнительно способствует уменьшение токсичности вод p. Магаданка после закрытия ряда промышленных предприятий в 1990-х гг.

Островные колонии. Мыс Островной. В течение всех лет наблюдения пресс человеческой деятельности на эту колонию не ослабевает: продолжает существовать «городок» из времянок рыбаков и краболовов у основания мыса, а поток туристов и отдыхающих, добирающихся до мыса по разбитой дороге и руслу ручья в летний период, не прекращается. В выходные и праздничные дни не менее десятка моторных и гребных лодок с рыбаками наблюдаются вокруг мыса. Морские птицы всегда занимали только ограниченную территорию мыса, которая практически недоступна для человека без альпинистского снаряжения.

Тренды развития колонии м. Островной лучше понятны, если одновременно рассмотреть процентное соотношение численности видов, составляющих колонию (см. рис. 3). Выделяются несколько «периодов» в истории существования колонии. Общая численность птиц в колонии возрастала в 2006 и 2011 г. и падала в 2009 и 2016 г. (см. рис. 2). При первом описании колонии (1991 г.) фоновыми видами колонии были очковый чистик и тихоокеанская чайка с небольшой долей моевки, гнездящейся на недоступном для людей скальном окончании мыса (см. рис. 3). Затем наблюдался стремительный рост общей численности птиц в колонии и появление на гнездовье нового вида - тонкоклювой кайры (2006 г.). По численности на первый план вышла тихоокеанская чайка. Моевка сравнялась по численности с чистиком (см. рис. 3). Спад численности колонии в 2009 г. был связан, по нашему мнению, с деградацией растительного покрова под влиянием жизнедеятельности очень большого количества тихоокеанских чаек на ограниченной площади и сползанию дернины на обрывах безлесного склона (Зеленская, 2012). В 2011 г. на обнажившихся скалах численность моевки продолжила расти, и этот вид стал вторым по численности, третьим фоновым видом оказалась тонкоклювая кайра (см. рис. 3). Последующая стабилизация ее численности (2016 г.), вероятно, объясняется ограниченной емкостью скал для размещения гнезд, куда не может добраться человек. Мы не имеем достаточно информации для объяснения причин снижения численности гнездящихся морских птиц в 2016 г. (см. рис. 2).

Вопрос о состоянии популяции очкового чистика в этой колонии остается открытым. В 2011 и 2016 г. не были проведены специальные учеты чистиков в период их максимальной активности, 
что дает большую вероятность недоучета. Возможно, нет сокращения их численности в доселе одной из наиболее крупных колоний этого вида в Тауйской губе.

O-ва Tри Брата. Общая численность птиц этой колонии с 1991 по 2017 г. стремительно растет (рис. 2). Соотношения численности разных видов морских птиц на о-вах Три Брата также значительно изменялись с течением лет. По первым упоминаниям, фоновым видом здесь была обыкновенная моевка. «Моевка в большом количестве гнездится на о-вах Три Брата в бух. Веселой в 1947 г.», - писал А. П. Васьковский (1956). В 1991 г. в этой колонии фоновыми были три вида: моевка, тихоокеанская чайка и тонкоклювая кайра (Голубова, Плещенко, 1997). По нашим данным, в 2005 г. фоновыми остаются моевки и кайры, а численность тихоокеанской чайки составляла уже менее $10 \%$ от общего числа птиц (см. рис. 4). С 2009 по 2017 г. лидирующую позицию по численности птиц этой колонии занимает тонкоклювая кайра (см. таблицу, рис. 4). Кайры гнездятся как на узких полках и в трещинах на вертикальных скалах, так и занимая сплошным ковром все более или менее ровные участки на вершинах и привершинных плоскогорьях и между камней.

Сохраняются все тенденции, отмеченные в 2009 г.: стремительный рост численности птицихтиофагов, добывающих мелкую рыбу как в толще воды и на глубине (кайра), так и в поверхностном слое (моевка). В 2009 г. отмечены на гнездовье виды, добывающие рыбу непосредственно около берега (чистики) или около дна (бакланы). Тогда же было зафиксировано появление топорков, для которых, казалось бы, на этих островках почти нет подходящих условий для устройства нор - скалистые крутые склоны почти полностью лишены дернины (Зеленская, 2012). В 2017 г. рост численности бакланов, чистиков и топорков продолжился, хоть и не такими быстрыми темпами (см. таблицу). На гнездовье в 2017 г. были отмечены еще два вида морских птиц: один видихтиофаг - ипатка и, впервые за многие годы отсутствия в этом районе, вид-планктофаг - белобрюшка.

Столь бурное развитие колонии, несмотря на не прекращающееся воздействие активности людей (лов крабов с гребных и моторных лодок попрежнему очень оживлен непосредственно около островков), свидетельствует о богатой кормовой базе, поддерживающей эту колонию. Наиболее вероятно, что способствует «обогащению» вод биогенами мощный приток сточных вод от м. Красный, сносимый течением к м. Восточный. Еще больше убеждает в «благотворности» антропогенного воздействия на прибрежную экосистему, способствующего процветанию ко- лоний морских птиц, изменение состояния колонии о. Кекурный, расположенного около места сброса сточных вод. Бурный рост численности моевок, бакланов и чаек за последнее десятилетие на этом крохотном островке и появление топорков, чистиков и ипаток, а также первая фиксация тонкоклювой кайры на его вершине говорят о хорошей кормовой базе для всех этих видовихтиофагов.

Сравнение истории развития колоний м. Островной и о-вов Три Брата, которые в 1991 г., до открытия сброса сточных вод у м. Красный, были примерно равны по численности (см. рис. 2), показывает принципиально разное направление антропогенного воздействия на гнездовья морских птиц. Обе колонии всегда испытывали примерно равное отрицательное воздействие присутствия людей (беспокойство, сбор яиц и пр.). В обеих колониях птицы адаптировались к этому воздействию, занимая недоступные для прямого воздействия людей территории. К 2016 г. колония м. Островной стала внешне более похожа на острова, составляющие архипелаг Три Брата: жизнедеятельность большого числа размножающихся чаек и вселившихся в 2006 г. кайр привела к обнажению скал на территории, занятой гнездовьями. В 2016 г. соотношение видов в колонии м. Островной стало сходным с соотношеним видов на о-вах Три Брата в 1991 г., до начала «удобрения» биогенами вод прибрежной акватории (см. рис. 3,4$)$.

Численность морских птиц, гнездящихся на м. Островной, колеблется по годам в ответ на воздействие разных природных факторов (помимо антропогенного пресса), в то же время численность колоний о-вов Три Брата только растет (см. рис. 2). Вероятно, все отрицательные воздействия компенсирует постоянное наличие добычи для морских птиц в акватории, удобренной сточными водами.

\section{ЗАКЛЮЧЕНИЕ}

За период с 2009 по 2019 г. на побережье и в окружающих бухтах п-ова Старицкого при постоянном высоком прессе деятельности человека численность гнездящихся морских птиц увеличилась с 36 тыс. до 57.6 тыс. особей. Распределение колоний вдоль побережья п-ова Старицкого изменилось мало: увеличилось число мелких колоний в районе м. Чирикова и на самом недоступном для высадки людей на берег участке побережья от м. Средний до м. Ольский.

Антропогенный пресс в отношении колоний морских птиц остается постоянным, нет периодов его спада или усиления. Он выражается в беспокойстве от регулярного появления людей в районе колоний и поступлении биогенов со сточными водами и со свалки ТБО. Сточные 
воды, вероятно, делают более продуктивным бентос бух. Гертнера, что отражается во взрывном росте численности гнездящихся здесь беринговых бакланов, кормящихся у дна. Колонии бакланов, гнездящихся на «Горняке», самые крупные в Тауйской губе.

Течения выносят сточные воды к о-вам Три Брата, и численность морских птиц в этой колонии также продолжает быстро расти. Колония Три Брата по численности сейчас почти в 4 раза крупнее колонии на м. Островной. Фоновые виды - ихтиофаги тонкоклювая кайра и моевка. За последнее десятилетие видовой состав этой колонии расширился с 6 видов (из них два были редко встречающимися) до 8. Появились ипатка и белобрюшка. Последний вид был отмечен здесь более 60 лет назад.

Продолжается рост урбанизированной популяции тихоокеанской чайки в зоне застройки г. Магадана, чему способствуют и свалка ТБО, и богатые кормом акватории бух. Гертнера и Нагаева. Рост городской популяции может быть обусловлен одновременно и эмиграцией чаек из окружающих природных колоний.

\section{БЛАГОДАРНОСТИ}

Автор крайне признателен О. А. Мочаловой (ИБПС ДВО РАН) за выполненную ею работу по проведению фотоучета на м. Островной в 2011 г. и предоставленные снимки. Без помощи Е. Р. Потапова (университет Филадельфии, США) учеты 2019 г. не могли бы состояться. Его же участие, как и коллег А. А. Примака и А. В. Кондратьева (ИБПС ДВО РАН), помогли провести учеты в 2017 г.

\section{ЛИТЕРАТУРА}

Артюхин Ю. Б., Зеленская Л. А. Командорская популяция серокрылой чайки Larus glaucescens: программа мониторинга и первые результаты ее выполне- ния // Сохранение биоразнообразия Камчатки и прилегающих морей : Доклады VIII междунар. науч. конф. 27-28 ноября 2007 г. Петропавловск-Камчатский : Камчатпресс, 2008. С. 16-35.

Васьковский А. П. Новые орнитологические находки на северном побережье Охотского моря // Зоологический журнал. 1956. Т. 35. Вып. 7. С. 1031-1058.

Голубова Е. Ю. Мониторинг популяций тонкоклювой (Uria aalge) и толстоклювой (Uria lomvia) кайр в Тауйской губе Охотского моря // Зоологический журнал. 2014. Т. 93, № 9. С. 1086-1105.

Голубова Е. Ю., Плещченко С. В. Колонии морских птиц северной части Охотского моря // Видовое разнообразие и состояние популяций околоводных птиц Северо-Востока Азии. Магадан : СВНЦ ДВО РАН, 1997. C. 141-162.

Зеленская Л. А. Гнездование тихоокеанской чайки Larus schistisagus на крышах зданий Магадана // Биология и охрана птиц Камчатки. 2004. № 6. С. 85-90.

Зеленская Л. А. Колонии морских птиц Тауйской губы и п-ова Кони (Охотское море) // Вестник СевероВосточного научного центра ДВО РАН. 2013. № 3. C. 87-100.

Зеленская Л. А. Состояние колоний морских птиц окрестностей г. Магадана // Вестник СевероВосточного научного центра ДВО РАН. 2012. № 2. C. $43-49$.

Зеленская Л. А. Экология питания берингова баклана, Fhalacrocorax pelagicus, в период гнездования // Зоологический журнал. 2001. Т. 80. Вып. 9. C. $1120-1130$.

Зеленская Л. А. Экология урбанизированной популяции тихоокеанской чайки (Larus schistisagus) в сравнении с естественными колониями. Особенности размещения гнезд и продуктивность // Зоологический журнал. 2019а. Т. 98. Вып. 4. С. 420-436.

Зеленская Л. А. Экология урбанизированной популяции тихоокеанской чайки (Larus schistisagus) в сравнении с естественными колониями. Питание и кормовые полеты // Зоологический журнал. 2019б. Т. 98. Вып. 8. С. 884-902.

Нечаев В. А., Гамова Т. В. Птицы Дальнего Востока России (аннотированный каталог). Владивосток : Дальнаука, 2009. 564 с.

\section{STATUS OF SEABIRD COLONIES ON THE STARITSKY PENINSULA (Tauy Bay, Sea of Okhotsk)}

\section{A. Zelenskaya}

\section{Institute of Biological Problems of the North, FEB RAS, Magadan}

Comparison of the 2019 census results with those obtained earlier permits to evaluate changes in the number and distribution of nesting seabird colonies on the Staritsky Peninsula over the past 10 years. The Staritsky Peninsula coasts and the Gertner and Veselaya bay islands are located in close proximity to the city of Magadan, and therefore are subject to maximum anthropogenic pressure. The total number of breeding seabirds (including the urban population of the Slaty-backed Gull in the city of Magadan) increased from 36 thousand individuals in 2009 to 57.6 thousand individuals 
in 2019. Simultaneously, the proportion of main species changed in the largest colonies around the city - on the Tri Brata Islands and Cape Ostrovnoy. A very large colony (3.230 birds) of the Pelagic Cormorants near the mouth of the Dukcha River, which appeared in the last 20 years, now became the largest in the Tauy Bay. The colony formation and growth was promoted by the urban wastewaters discharged into the Gertner Bay.

\section{Keywords: seabird colony, number of seabirds, distribution of breeding seabird colonies, anthropogenic pollution of waterways, Tauy Bay, Staritsky Peninsula, Tri Brata Islands, Cape Ostrovnoy.}

\section{REFERENCES}

Artukhin, Yu. B., Zelenskaya, L. A., 2008. The Commander Islands Glaucous-Winged Gull Larus glaucescens Population: Monitoring Program and First Results of Study, Conservation of Biodiversity of Kamchatka and Adjacent Seas. Proceeding of VIII International Scientific Conference. Petropavlovsk-Kamchatsky, November 27 28, 2007. 16-35 [In Russian].

Golubova, E. Yu., 2014. Monitoring of the Common Murre (Uria alge) and Thick-Billed Murre (Uria lomvia) Populations from Tauiskaya Bay, the Sea of Okhotsk, Zoologicheskii Journal. 93 (9), 1086-1105 [In Russian].

Golubova, E. Yu., Pleschenko, S. V., 1997. Seabird Colonies of the North Okhotsk Sea Region, in Species Diversity and Population Status of Waterside Birds in NorthEast Asia. Magadan. 141-162 [In Russian].

Nechaev, V. A., Gamova, T. G., 2009. Birds of Russian Far East (an Annotated Catalogue). Vladivostok, Dalnauka [In Russian].

Vaskovsky, A. P., 1956. New Ornithological Finds at the Sea of Okhotsk Northern Coast, Zoologicheskii Zhurnal. 35 (7), 1031-1058 [In Russian].

Zelenskaya, L. A., 2001. Feeding Ecology of the Pelagic Cormorant, Fhalacrocorax pelagicus, in the Breed- ing Period, Zoologicheskii Zhurnal. 80 (9), 1120-1130 [In Russian].

Zelenskaya, L. A., 2004. Roof-Nesting of SlatyBacked Gulls Larus schistisagus in Magadan-City, The Biology and Conservation of the Birds of Kamchatka. 6, 85-90 [In Russian].

Zelenskaya, L. A., 2012. The Condition of Seabird Colonies around the City of Magadan, Vestnik NESC FEB RAS. 2, 45-49 [In Russian].

Zelenskaya, L. A., 2013. Seabird Colonies in the Tauy Bay and on the Koni Peninsula (Sea of Okhotsk), Vestnik NESC FEB RAS. 3, 87-100 [In Russian].

Zelenskaya, L. A., 2019a. Ecology of the Urban Population of the Slaty-Backed Gull (Larus schistisagus) in Comparison with Natural Colonies. 1. Features of Nest Location and Productivity, Zoologicheskii Zhurnal. 98 (4), 420-436 [In Russian].

Zelenskaya, L. A., 2019б. Ecology of Urban Population of the Slaty-Backed Gull (Larus schistisagus) in Comparison with Natural Colonies. 2. Feeding and Foraging Flights, Zoologicheskii Zhurnal. 98 (8), 884-902 [In Russian]. 